University of Nebraska - Lincoln

DigitalCommons@University of Nebraska - Lincoln

Faculty Publications: Department of

Entomology

Entomology, Department of

2009

\title{
Apparent Hybridization Between Trimerotropis agrestis and Trimerotropis maritima (Orthoptera: Acrididae) in a Recently Disturbed Habitat
}

\author{
Mathew L. Brust \\ Chadron State College, mbrust@csc.edu \\ W. Wyatt Hoback \\ University of Nebraska at Kearney, whoback@okstate.edu \\ Robert J. Wright \\ University of Nebraska, rwright2@unl.edu
}

Follow this and additional works at: https://digitalcommons.unl.edu/entomologyfacpub

Part of the Entomology Commons

Brust, Mathew L.; Hoback, W. Wyatt; and Wright, Robert J., "Apparent Hybridization Between Trimerotropis agrestis and Trimerotropis maritima (Orthoptera: Acrididae) in a Recently Disturbed Habitat" (2009).

Faculty Publications: Department of Entomology. 186.

https://digitalcommons.unl.edu/entomologyfacpub/186

This Article is brought to you for free and open access by the Entomology, Department of at DigitalCommons@University of Nebraska - Lincoln. It has been accepted for inclusion in Faculty Publications: Department of Entomology by an authorized administrator of DigitalCommons@University of Nebraska - Lincoln. 


\title{
Apparent Hybridization Between Trimerotropis agrestis and Trimerotropis maritima (Orthoptera: Acrididae) in a Recently Disturbed Habitat
}

\begin{abstract}
Mathew L. Brust, ${ }^{1}$ W. Wyatt Hoback, ${ }^{2, *}$ and R. J. Wright ${ }^{3}$
ABSTRACT: In Nebraska, the ranges of Trimerotropis maritima (eastern species) and $T$. agrestis (western species) overlap but populations usually remain separated by habitat preferences. The morphological and color differences between the species are described. However, around Lake McConaughy, a reservoir on the North Platte River which has declined markedly in depth as a result of recent drought, a habitat was created in which the two species coincide and hybridize frequently. The water level in this reservoir had dropped in excess of 20 meters as of 2007, resulting in large expanses of dunes grading into beach habitats. Grasshoppers were collected in the area from 2005 to 2007 and based on morphological characteristics appear to represent hybrids. Surveys of many other habitats in Nebraska produced no hybrids. This study indicates that the alteration of habitat by impoundment of a river followed by climatic change may have the potential to disrupt environmental boundaries that maintain the integrity of parapatric sibling species.

As this habitat is the result of human landscape alterations, it suggests that our alterations have the potential to disrupt environmental characteristics that maintain the integrity of parapatric sibling species.

KEY WORDS: Acrididae, Trimerotropis, hybridization, habitat change, biodiversity loss
\end{abstract}

Hybrids between closely related species are well known in disturbed areas, especially in plants. We present here such a case in grasshoppers. Short-horned grasshoppers (Acrididae) in the genus Trimerotropis are notoriously difficult to identify to species and some recognized species appear to hybridize in limited areas (Otte, 1984). Members of this genus typically live in areas with sparse vegetation, are cryptically colored, but usually have hind wings that are banded and colored. Only a limited number of features appear to be useful for separating many of the known North American species (Otte, 1984).

While apparent hybridization has been suggested between several species, it has not been noted previously between Trimerotropis agrestis McNeill and Trimerotropis maritima (Harris). Both of these species occur in sandy areas with sparse vegetation; however, $T$. agrestis inhabits upland sites such as dunes, blowouts, and intermittent gravelly streambeds (Hagen, 1970; Otte, 1984; Helfer, 1987), while T. maritima is usually found in lowland habitats such as sandbars, beaches, and shorelines (Blatchley, 1920; Otte, 1984). Trimerotropis agrestis is a western species with known eastward distribution to the region of mixed-grass prairie, while T. maritima ranges across the eastern United States west to Colorado and eastern Arizona in the

\footnotetext{
${ }^{1}$ Department of Biology, Chadron State College, 1000 Main Street, Chadron, Nebraska 69337.

${ }^{2}$ Department of Biology, University of Nebraska at Kearney, 905 W 25th Street, Kearney, Nebraska 68849.

${ }^{3}$ Department of Entomology, University of Nebraska Lincoln, 202 Plant Industry Building, Lincoln, Nebraska 68583-0816.

* Author to whom proofs should be sent, email: hobackww@unk.edu, phone: (308) 865-8602. 
Table 1. Collection locations and number of specimens examined from each location.

\begin{tabular}{llc}
\hline \multicolumn{1}{c}{ Location } & Trimerotropis agrestis (suspected) \\
\hline NA & County & Number examined \\
Lake McConaughy & Garden & 1 \\
NA & Keith & $41^{*}$ \\
\hline & Thomas & 4 \\
\hline \multicolumn{1}{c}{ Location } & Trimerotropis maritima \\
\hline Bassway Strip SWMA & County & Number examined \\
Blue Hole SWMA & Buffalo & 21 \\
Cherry Creek & Buffalo & 7 \\
Cottonmill Park & Buffalo & 2 \\
Lexington & Buffalo & 4 \\
Overton & Dawson & 6 \\
Cambridge & Dawson & 1 \\
Harlan Reservoir & Furnas & 5 \\
Fawn Woods Lake & Harlan & 1 \\
Ogallala & Kearney & 1 \\
Roscoe & Keith & 19 \\
Brached Oak Lake SRA & Keith & 14 \\
Yankee Hill SWMA & Lancaster & 4 \\
Brady & Lancaster & 2 \\
North Platte & Lincoln & 1 \\
\hline & Lincoln & 5 \\
\hline Includ & & \\
\hline
\end{tabular}

* Includes intermediates.

southern part of its range (Otte, 1984). Because of their similarity in appearance, they have frequently been confused in collections (Hebard, 1931; Hagen, 1970).

Two primary characters appear to reliably separate these species. Both Otte (1984) and Helfer (1987) found that the lateral lobes of the pronotum in T. agrestis are much more extended and pointed than in T. maritima and present diagrams to aid in identification. Both species have two black bands on the inner surface of the hind femur, but the illustration presented by Otte (1984) shows T. maritima as having a whitish ground color, while T. agrestis has the ground color orange to pinkish. Both species have red to orange hind tibiae, but in T. maritima they may also be yellowish to buff. As indicated below, additional characters are the dark lateral pronotal spot in T. maritima and the maculation of the tegmina, which in T. maritima usually appear to be indistinctly banded, but in T. agrestis any banding is reduced to small spots (see Otte, 1984; Plate 15).

Based on material collected in Nebraska, we present evidence for limited hybridization between these two species. In Nebraska, it appears that habitat changes associated with dam construction followed by prolonged drought have allowed the ranges of these two species to overlap, resulting in apparent interbreeding.

\section{Materials and Methods}

Large series of T. maritima and T. agrestis were collected from across Nebraska between 2005 and 2007. Table 1 displays the number of specimens examined and the locations from which material was collected. Specimens were initially identified to species based on general appearance, but were later re-inspected. In particular, one 


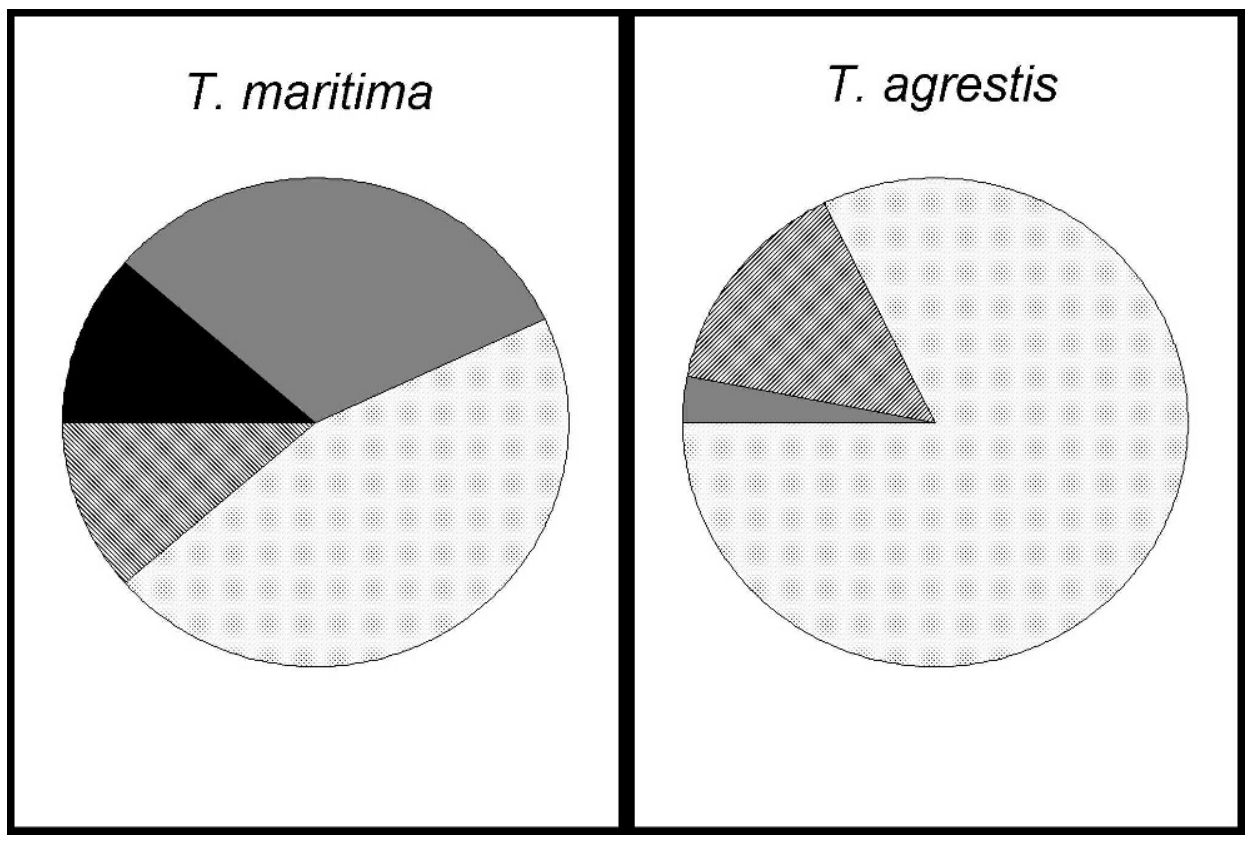

Fig. 1. Proportion of Trimerotropis maritima $(n=94)$ and Trimerotropis agrestis $(n=45)$ specimens from throughout Nebraska with each developmental state of dark markings on the sides of the pronotum. Black $=$ lacking, gray $=$ poorly developed, stripes upper left to lower right $=$ moderately developed, stipple upper right to lower left $=$ well developed.

series appeared to contain both species as well as many specimens which had intermediate characteristics.

Specimens were examined according to characters presented in Otte (1984), and the shape of the lateral lobe of the pronotum was recorded as matching that of Fig. 50c ( $T$. agrestis) or 50d (T. maritima) (Otte, 1984, p. 183). In addition we recorded the ground color of the inner surface of the hind femur as well as the color of the hind tibia. Based on observations of Nebraska specimens, we also quantified the development of a dark marking or spot on the sides of the pronotum, which appeared to be consistently present in T. maritima but generally lacking in $T$. agrestis.

All specimens used in this study are currently housed at the U.S. Department of Agriculture's Animal and Plant Health Inspection Service in Lincoln, Nebraska.

\section{Results}

All T. maritima examined from riverine and lakeshore habitats with the exception of Lake McConaughy had lateral pronotal lobes which fit the form indicated for the species by Otte (1984). Additionally, over $90 \%$ of specimens exhibited dark markings on the sides of the pronotum moderately or well-developed (Fig. 1) and no specimens of this species lacked these markings. The single specimen collected from a blowout in Thomas County (identification based on shape of lateral lobe) had these markings poorly developed (Table 2). Of the four T. agrestis specimens collected from blowout habitats in Garden and Thomas Counties, all had pronotal lobes matching those described for that species and had the lateral areas of the pronotum 
Table 2. Evidence suggesting hybridization.

\begin{tabular}{|c|c|c|c|}
\hline Character & Typical T. agrestis & Lake McConaughy population & Typical T. maritima \\
\hline Lateral pronotal lobe & extended as in Fig. 2 & $\begin{array}{l}43.9 \% \text { as in Fig. } 2 \\
39.0 \% \text { intermediate } \\
17.1 \% \text { as in Fig. } 6\end{array}$ & right angular as in Fig. 6 \\
\hline $\begin{array}{l}\text { Inner surface of hind } \\
\text { femur }\end{array}$ & orange to pinkish & $\begin{array}{l}26.8 \% \text { orange to pinkish } \\
73.2 \% \text { buff or whitish }\end{array}$ & whitish, yellowish, or buff \\
\hline $\begin{array}{l}\text { Dark mark on side } \\
\text { of thorax }\end{array}$ & absent & $\begin{array}{l}61.0 \% \text { well developed, present } \\
31.7 \% \text { weak } \\
7.3 \% \text { absent }\end{array}$ & $\begin{array}{l}90 \% \text { present } \\
10 \% \text { weak }\end{array}$ \\
\hline
\end{tabular}
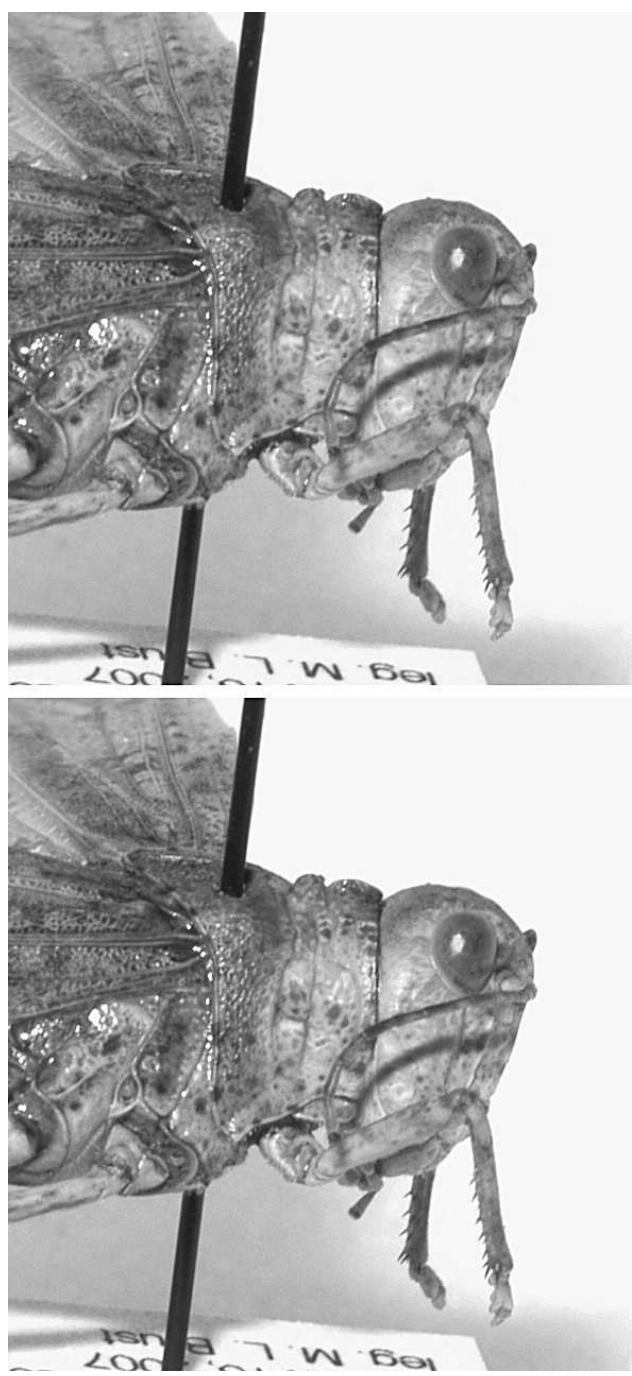

Fig. 2. Lateral lobes of the pronotum on two specimens of Trimerotropis agrestis from Thomas County, Nebraska, showing poorly developed or lacking lateral pronotal markings. 


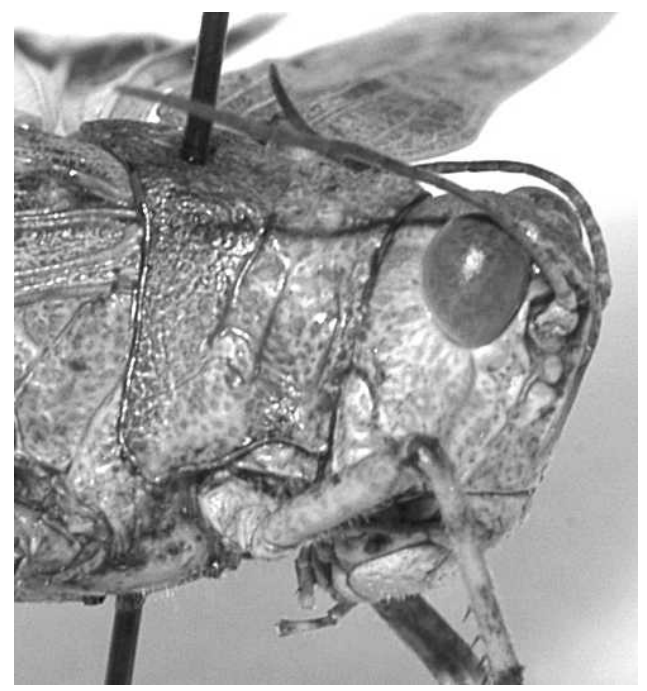

Fig. 3. Lateral lobes of the pronotum on one specimen of Trimerotropis agrestis (suspected) from Lake McConaughy in Keith County, Nebraska.

poorly developed or lacking. Among all of the presumed T. agrestis, over half had the lateral pronotal markings poorly developed or lacking (Fig. 2). The majority of these were collected from Lake McConaughy.

All specimens from the dunes surrounding Lake McConaughy were originally identified as $T$. agrestis based on habitat and the reduced markings on the tegmina. However, in the characters we examined, there is continuous gradation between $T$. agrestis and T. maritima within this population. For example, of the 41 presumed T. agrestis from that site, 16 had lateral lobes that appeared intermediate between the two species, and 7 had lateral lobes resembling those of T. maritima (Table 2). Among the suspected $T$. agrestis from Lake McConaughy, about a third of the series appears to represent hybrids between $T$. agrestis and T. maritima based on the shape of the lateral lobe of the pronotum. About one-sixth of this series appear to be $T$. maritima based on lateral lobe shape, and all of these specimens displayed white as the ground color of the surface of the inner hind femur, also consistent with $T$. maritima. Nearly half of the series from this site exhibited lateral lobes with shapes consistent with $T$. agrestis. This suggests that at this site there is significant hybridization between these two species. Figures 3-6 show representative specimens from different parts of Nebraska for reference.

\section{Discussion}

Lake McConaughy is the largest reservoir in Nebraska. In recent years the water level has receded dramaticlly, exposing dunes in areas that were once below water as a result of drought. As of October 2007, the reservoir remained $17.5 \mathrm{~m}(57.3 \mathrm{ft})$ below maximum level (Nebraska Game and Parks Commission 2007). Several upland dune tiger beetles have colonized this site in recent years, and another dune grasshopper, Xanthippus montanus (Thomas), was collected there in 2006. As a result of the water recession, dunes now grade directly into beach habitats, which has likely 

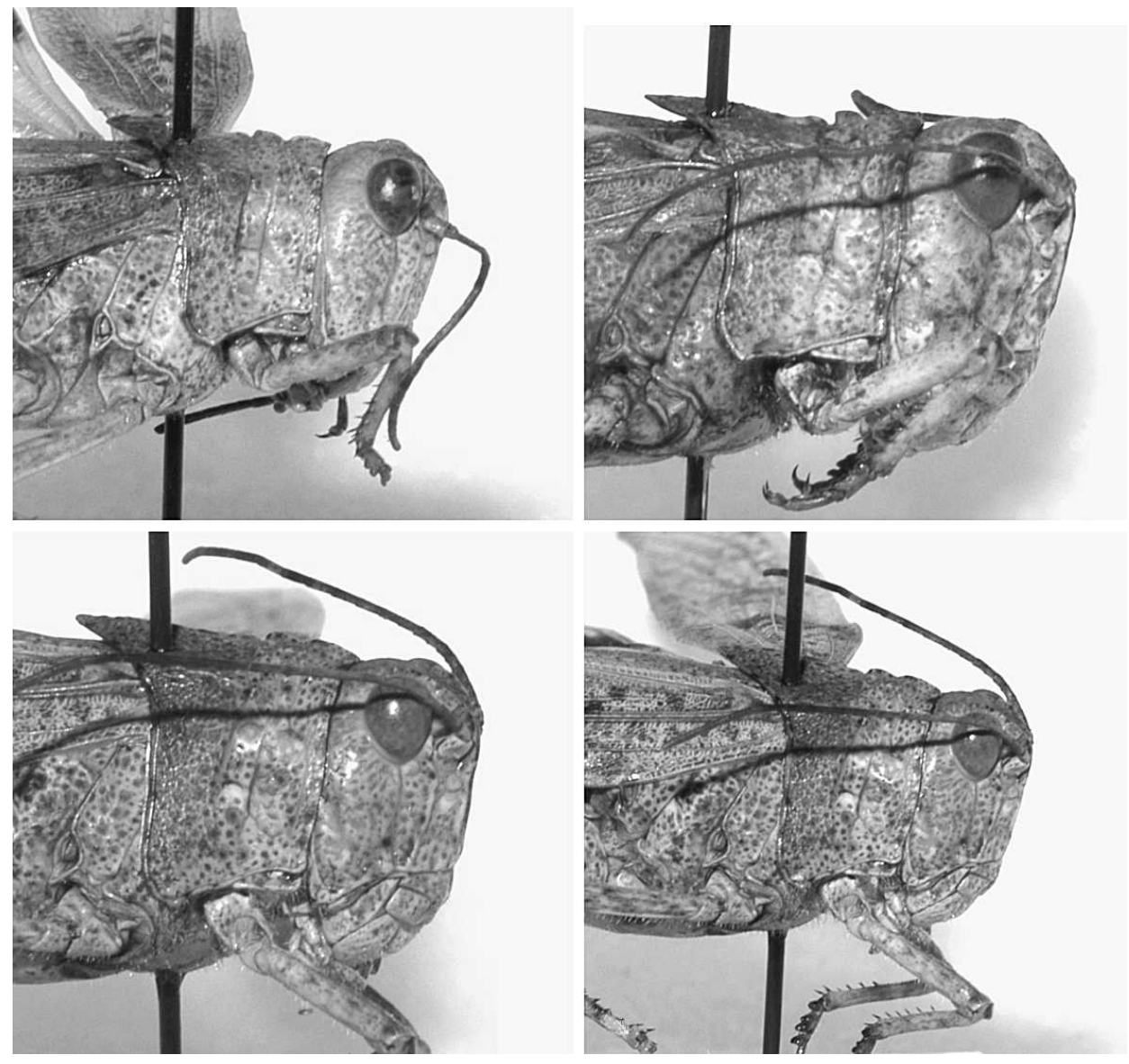

Fig. 4. Lateral lobes of the pronotum of four specimens of Trimerotropis agrestis $\times$ maritima hybrids (suspected) from Lake McConaughy in Keith County, Nebraska.

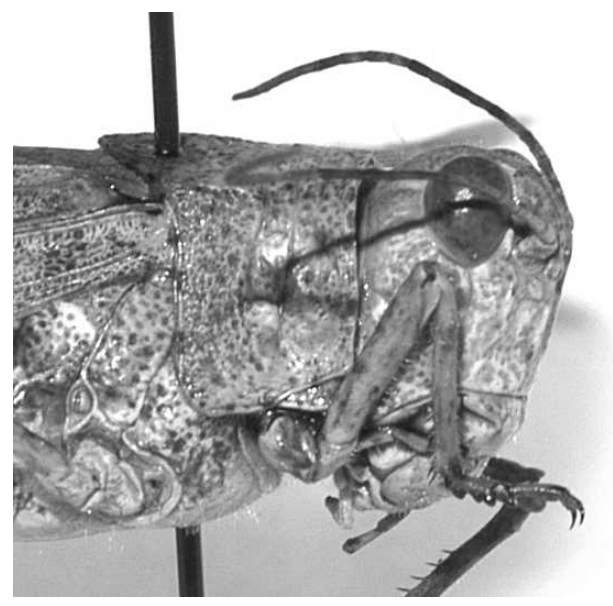

Fig. 5. Lateral lobes of the pronotum of one specimen considered to be Trimerotropis maritima (suspected) from Lake McConaughy in Keith County, Nebraska. 

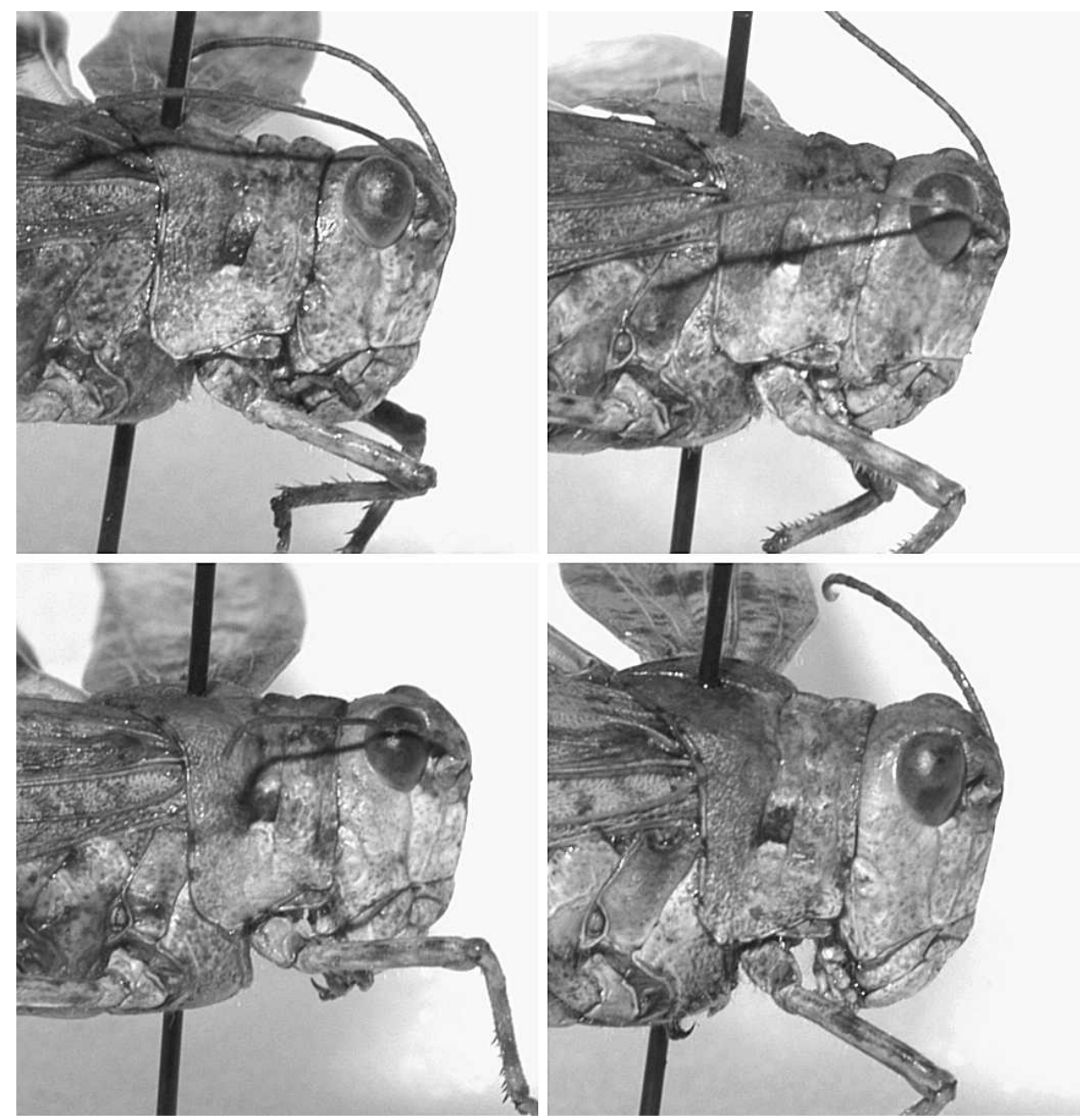

Fig. 6. Lateral lobes of the pronotum of four specimens of Trimerotropis maritima from riverine habitats in central Nebraska. In rows from upper left; 1 = Bassway Strip SWMA, Buffalo County; 2 and $3=$ Roscoe, Keith County; 4 = North Platte, Lincoln County. Note the dark spot evident on the side of the pronotum in these specimens.

allowed T. agrestis and T. maritima to co-occur, a phenomenon that probably only occurs rarely under natural conditions. While it is unknown if these hybrids are sterile, this is unlikely as individuals appear to present a complete gradation in form between these two species. In addition, the grasshoppers are abundant at Lake McConaughy, suggesting that the preponderance of hybrids is having little, if any, effect on reproduction.

This study reveals that human impacts on ecological barriers separating closely related species can be exacerbated by abnormal weather conditions. It is unknown how commonly these two species hybridize under natural condition, but the lack of previous reports in the literature suggests that it is uncommon. Future studies should examine these species and suspected hybrids using molecular techniques. Further, 
this population should be monitored when climatic conditions change and Lake McConaughy returns to normal.

\section{Literature Cited}

Blatchley, W. S. 1920. Orthoptera of Northeastern America, with especial reference to the faunas of Indiana and Florida. The Nature Publishing Company; Indianapolis, IN. 784 pp.

Hagen, A. F. 1970. An annotated list of grasshoppers (Orthoptera: Acrididae) from the eleven panhandle counties of Nebraska. University of Nebraska Resource Bulletin 238:1-60.

Hebard, M. 1931. The Orthoptera of Kansas. Proceedings of the Academy of Natural Sciences, Philadelphia 83:119-227.

Helfer, J. R. 1987. How to Know the Grasshoppers, Crickets, Cockroaches and Their Allies. Dover Publications Inc; New York, NY. 363 pp.

Otte, D. 1984. The North American Grasshoppers, Vol. 2, Acrididae: Oedipodinae. Harvard University Press; Cambridge, MA. 366 pp. 